\title{
Used Oil Storage and Disposal Practices in Automobile Repair Garages in Ghana
}

\author{
Akpakpavi Michael \\ Mechanical Engineering Department, Accra Polytechnic, Accra, Ghana \\ Email address: \\ micakpakpavi@yahoo.com \\ To cite this article: \\ Akpakpavi Michael. Used Oil Storage and Disposal Practices in Automobile Repair Garages in Ghana. International Journal of Science, \\ Technology and Society. Vol. 3, No. 4, 2015, pp. 191-201. doi: 10.11648/j.ijsts.20150304.23
}

\begin{abstract}
This study investigates the used oil storage and disposal practices in automobile repair garages in Ghana. The data for the study were collected using questionnaire, observations and personal discussions. One hundred and fifty informal sector garages and 100 formal sector garages made up the analyzed sample size. The results of the analysis reveal that a very large majority of the auto repair garages in the country lack used oil storage and disposal standards. Also, the garages do not organize training programs to educate and sensitize the mechanics about the health and environmental hazards of used oils. Again, proper used oil storage and disposal practices are virtually absent in the auto repair garages, coupled with lack of licensed used oil collection centers, transporters and recyclers in the country. This therefore, has caused used oil generators in the country to engage in an undesirable used oil disposal practices which pollute the environment excessively. To help address this issue, the Environmental Protection Agency (EPA)-Ghana's by-laws on used oil handling and disposal practices must be vigorously enforced. The EPA must also intensify its visits to the garages to educate and sensitize them on proper used oil storage and disposal practices. The Government, the Banks, philanthropies and wealthy individuals in the country should help establish used oil collection centers in the country to enable the mechanics sell off their generated used oils for recycling. Government must assistant the endowed garages in the country to enable them develop the capability to recycle their generated used oils. This will help create more jobs and enhance the revenue base of government as a result of cut downs on the importations of virgin motor oils into the country.
\end{abstract}

Keywords: Used Oil, Storage, Disposal, Automobile Repair Garages, Ghana

\section{Introduction}

\subsection{Background}

Automotive repair garages play a critical role in the automotive industry in every economy since they help repair and maintain the vehicles on the roads. Typical vehicle maintenance activities include oil and filter changes, battery replacement, light metal machining et cetera. Potential wastes generated as a result of vehicle maintenance and repair activities are: used oils, spent fluids, spent batteries, asbestos brake pads and linings, metal machining wastes, spent organic solvents, and tires. These wastes have the potential to be released to the environment if not handled properly, stored in secure areas with secondary containment, and/or protected from exposure to weather. If released to the environment, the impact of these releases can be contamination of surface waters, ground water and soils, as well as toxic releases to the air [1-2]. Moreover, used motor oil contains numerous toxic substances, including polycyclic aromatic hydrocarbons, which are known to cause cancer. In addition, tiny pieces of metal from engine wear and tear, such as lead, zinc and arsenic, make their way into lubricants, further contributing to the polluting potential of used motor oil. Because used motor oil is heavy and sticky, and contains an extensive concentrated cocktail of toxic compounds, it can build up and persist in the environment for years [3-5]. Indeed, a paper presented by Nwachukwu et al (2012) shows the environmental impact assessment of used engine oil (table 1). 
Table 1. Environmental impact assessment of local uses of changed engine oil.

\begin{tabular}{|c|c|c|}
\hline Local uses of used oil & Application & Environmental effect \\
\hline Road construction & On the ground & Soil pollution \\
\hline Rust prevention & On a metal device & Stains on contact \\
\hline $\begin{array}{l}\text { Old engines emergency } \\
\text { lubrication }\end{array}$ & $\begin{array}{l}\text { Automobiles, } \\
\text { Generators }\end{array}$ & Air pollution, \\
\hline Wood preservation & $\begin{array}{l}\text { Timber, roofing, } \\
\text { fencing }\end{array}$ & Land pollution \\
\hline $\begin{array}{l}\text { Mixed with grease for } \\
\text { gear oil }\end{array}$ & $\begin{array}{l}\text { Gear box } \\
\text { lubrication }\end{array}$ & Spills, soil pollution \\
\hline Burning, Boilers, furnaces & $\begin{array}{l}\text { Burners, bakery, } \\
\text { incinerators }\end{array}$ & Off-gas, air pollution \\
\hline $\begin{array}{l}\text { For pest, weed, and dust } \\
\text { control }\end{array}$ & Garden, workshops & Soil pollution \\
\hline $\begin{array}{l}\text { Ball joint oil and nuts } \\
\text { loosing oil }\end{array}$ & $\begin{array}{l}\text { Ball and socket } \\
\text { joints, nuts }\end{array}$ & Stains on contact \\
\hline $\begin{array}{l}\text { Block and Balustrade } \\
\text { mold lubricant }\end{array}$ & $\begin{array}{l}\text { Block, balustrade } \\
\text { molds }\end{array}$ & Spills, land pollution \\
\hline Dust and tick control & Land, floor & Land pollution \\
\hline
\end{tabular}

Source: Nwachukwu et al (2012)

To help address the problem of used oil pollutions in the environment, laws, regulations and standards on proper storage and disposal of used oils are enacted and enforced in most developed and developing countries to ensure that vehicle repair garages in these countries properly store and reasonably dispose off their generated waste oils.

Unfortunately, the disposal of waste oil into gutters, water drains, open vacant plots, farms and so on is a common practice in Ghana especially by motor mechanics. Conspicuously, large quantities of used oil generated in the garages in the country tend to be dumped around the cities in drains which ultimately contaminate and pollute water bodies including rivers, lagoons, streams, etc. Examples of water bodies polluted by the dumping of used lubricating oils, greases, etc. from automobile service garages abound and these include the Odaw River and Korle Lagoon in Accra, Fosu Lagoon in Cape Coast, and so on [6]. Undoubtedly, this indiscriminate dumping of waste oils in the water bodies in the country could largely be attributed to the mechanics gross lack of knowledge regarding the physical and environmental hazards of the used oils.

This study therefore, investigates motor oil storage and disposal practices in automobile repair garages in Ghana. It is the believe of the researcher that this paper would help educate and sensitize the automobile repair garages in the country about the hazards associated with used oils and their proper methods of storage and disposal approaches to avoid polluting the environment unjustifiably.

\subsection{The Automobile Repair Garages in Ghana}

In Ghana, the most common automobile repair garages are the local garages where a group of automotive mechanics come together to offer automotive maintenance and repair services. They operate under the informal sector with usually one master owning the shop. The garages are normally built on a piece of land hired from a landlord. Again, in a classical local automotive repair garage not less than three master mechanics are available with each master having specialized area of auto repairs as automotive electrical specialist, mechanic specialist, vehicle body works specialist, brake binding specialist et cetera. Moreover, each master normally has apprentice trainees who study under them.

The second categories of vehicle repair garages are those that operate under the formal sector and they include: automobile repair workshops that are owned by one person but employs automotive mechanics specialized in different areas. These garages engage in the repair and maintenance of vehicles and are few in number in the country. Workshops owned by international automobile companies also operate under the formal sector and are opened to the general public for general vehicle repair and maintenance. Typical examples include Silver Star Ltd, Toyota Ghana Ltd, Rana Motors, Mechanical LIoyed, PHC Motors etc. Again, in Ghana, there are automotive repair garages in government organizations or institutions such as Ministry of Food and Agriculture, Ministry of Health, Ghana Water Company Ltd, Ghana Audit Service etc. In these organizations, the vehicles of the institutions are repaired and maintained. Moreover, most of these workshops are not opened to public vehicle owners for vehicle servicing activities. Besides, all these garages operate under the formal sector.

\section{Methods}

\subsection{Study Area Description}

The study was carried out in four main industrial areas in Ghana, where particularly local automobile repair garages were dominant including: Kumasi, Takoradi, Accra and Tema. The survey was confined to these places because most industrial activities are concentrated there [7]. Certainly, this finding is still the same now. Also, the four centers mentioned are all urban areas. Hence, it was taught that the views of the respondents from these centers would adequately represent the whole population.

The researcher classified the automobile repair garages into two categories. Category A represents vehicle repair garages in the informal sector generally known as micro and small scale enterprises (MSEs). These informal micro and small scale garages are numerous and they are dotted all over the country. Hence, a very large number of the automotive garages in the country are in the informal sector. They are patronized by many vehicle owners in the country because of their low works charges and proximity. Category $\mathrm{B}$ consists of automobile repair garages in the formal sector, registered in the Ghana's trade register as small and medium scale enterprises (SMEs).

\subsection{Data Collection Techniques}

The study used multi approach techniques in data collection. It involved observation, personal discussions and questionnaire administration to workers from each category of automobile repair garages identified. This approach was chosen to increase the validity of the study by enriching the 
scope, depth and knowledge derived from the data.

\subsubsection{Observations}

Observations were made by the researcher by visiting the two categories of the automobile repair garages identified three times on different occasions informally. During the trip, used oil storage and disposal practices by each category of garage was observed, noted and where necessary recorded.

\subsubsection{Sampling}

In all, 250 automobile repair workers who responded to the questionnaire make up the sample size. One hundred and fifty respondents were from the informal micro and small scale garages, whiles one hundred respondents were from the formal small and medium scale garages in Ghana. All the mechanics from both formal and informal sectors were randomly selected. However, the garage owners, workshop supervisors and transport officers in both the formal and inform sectors were purposively selected and they were also included in the total sample.

\subsection{Data Analysis}

Data extracted from the administered questionnaires and interview were analyzed using statistical tools such as pie charts, tables and bar charts for percentile analysis [8].

\section{Results}

\subsection{Educational Levels and Working Experience of Mechanics in the Automotive Repair Garages}

With regard to educational levels of mechanics in the informal auto repair garages in the country, about $5 \%$ had education up to tertiary levels, $21 \%$ had secondary/technical levels of education, $30 \%$ have had basic education levels whiles close to $44 \%$ of the mechanics in the informal sector had apprenticeship form of education. This finding is as illustrated in fig. 1 .

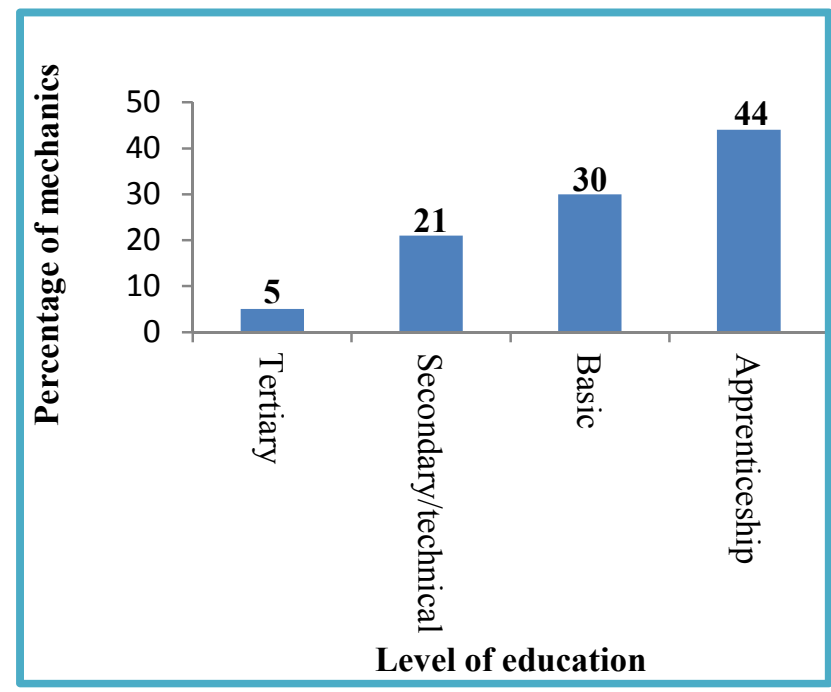

Fig. 1. Educational levels of mechanics in the informal sector garages.
Moreover, the mechanics in the formal sector automobile repair garages who responded to the questionnaire on their educational levels indicated that about $55 \%$ had tertiary levels of education, $26 \%$ had secondary/technical levels of education, $11 \%$ had basic education levels whiles the remaining $8 \%$ had apprenticeship form of education. This is pictured in fig. 2

On the issue of working experience of mechanics in the country, about $70 \%$ of the mechanics in both the formal and informal auto repair garages in the country had more than ten years working experience whiles the remainder $30 \%$ have had between 1-6 years working experience. This is pictured in fig. 3

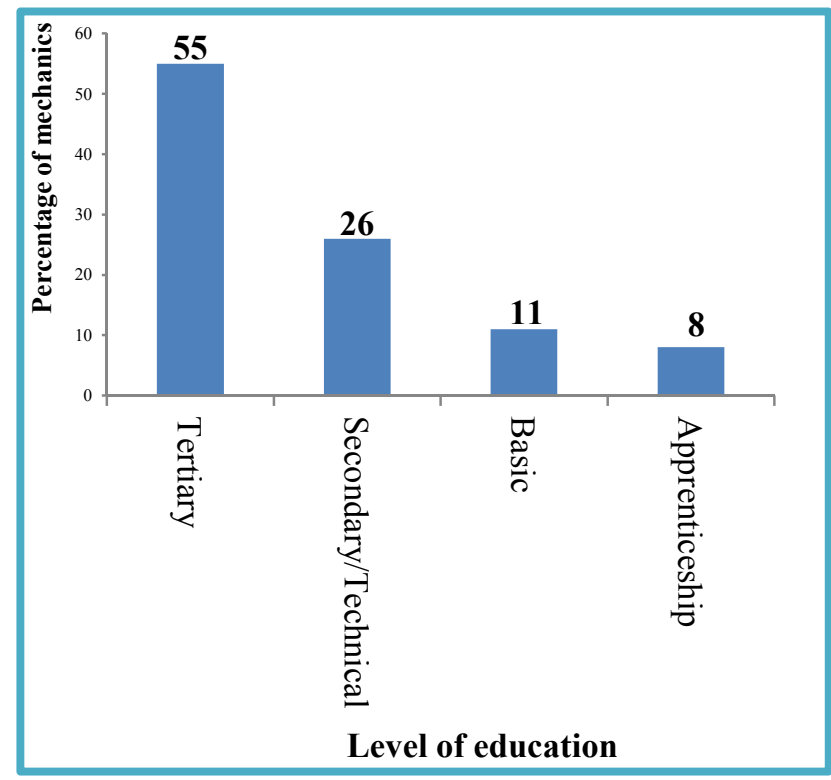

Fig. 2. Educational levels of mechanics in the formal sector garages.

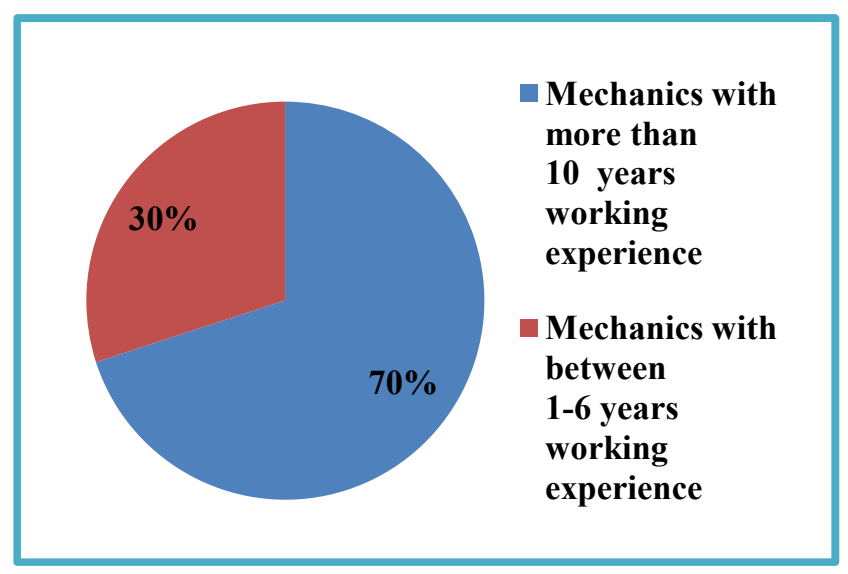

Fig. 3. Working experience of mechanics in the garages in the country.

\subsection{Availability of Used Oil Management Standards in Automobile Repair Garages}

Used oil disposal standards play a critical role in ensuring that vehicle repair garages properly handle and dispose of their used oils in such a manner to minimize oil leakages into the environment. However, on the issue of availability of used oil disposal standards in the garages in Ghana, about $5 \%$ of the vehicle repair garages in the formal and informal sectors had 
adopted some standards; whiles $95 \%$ had no waste oil disposal standards. This is shown in fig. 4.

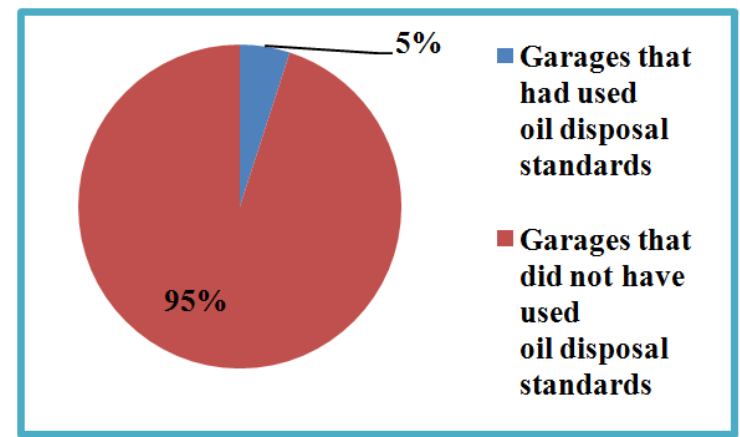

Fig. 4. Availability of Used oil management standards in the vehicle repair Garages

\subsection{Education and Training on Hazards of Used Oil for Auto Mechanics}

On the issue of education and training to help raise the awareness of the auto mechanics on the health and environmental hazards of used oil, about $5 \%$ of the mechanics in the informal micro and small scale sector had had it, whiles the remainder $95 \%$ were completely oblivious of the environmental hazards of the used oils. This is illustrated in fig. 5.

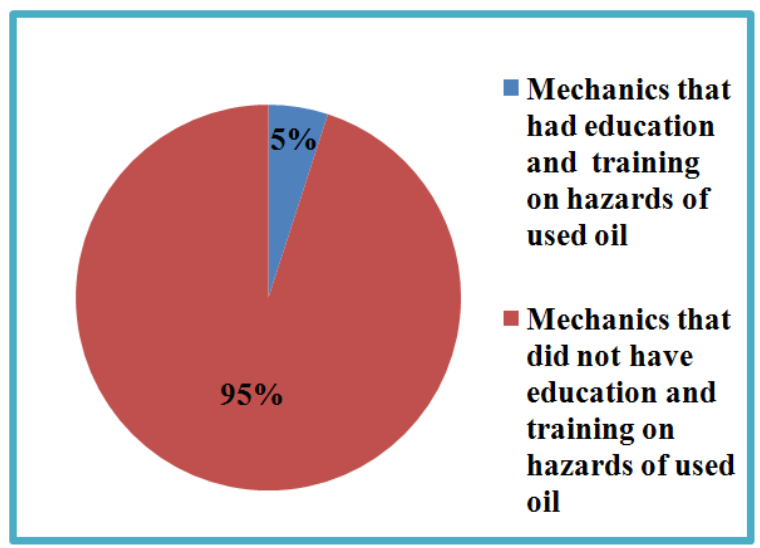

Fig. 5. Training on used oil hazards for informal sector mechanics.

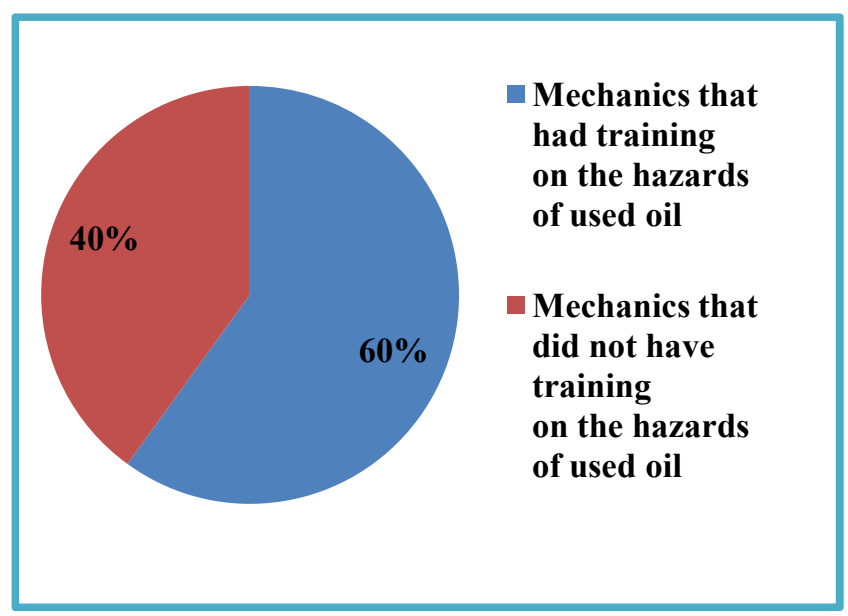

Fig. 6. Training on used oil hazards for formal sector mechanics.
Moreover, on the same issue of education and training on health and environmental hazards of used oil, about $60 \%$ of the mechanics in the formal sector had it, whilst the remainder $40 \%$ did not have it. This finding is as presented in fig.6.

\subsection{Problems of Storage of Used Oils and Other Materials by Garages}

On the above issue, about $85 \%$ of the garages in the formal and informal sector did have no problems with storage of their generated used oils for subsequent disposal whiles $15 \%$ did have storage problems of their generated used oils. This finding is depicted in fig. 7

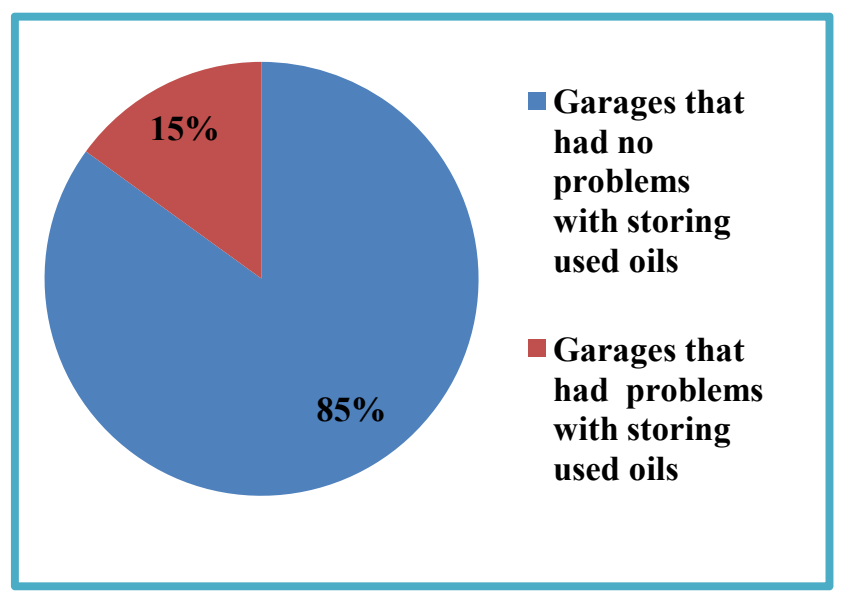

Fig. 7. Problems of storage of used oils by garages.

\subsection{Disposal of Used Oil by Garages}

With regard to the responses given by the garages on their used oil disposal approaches, $60 \%$ of the garages sold their generated used oil, $25 \%$ of the garages poured their generated used oil into the environment, $10 \%$ gave away the used oil for free whiles the remaining $5 \%$ of the vehicle repair automobile garages gave away their generated used oil to their clients. This finding is illustrated in fig. 8 .

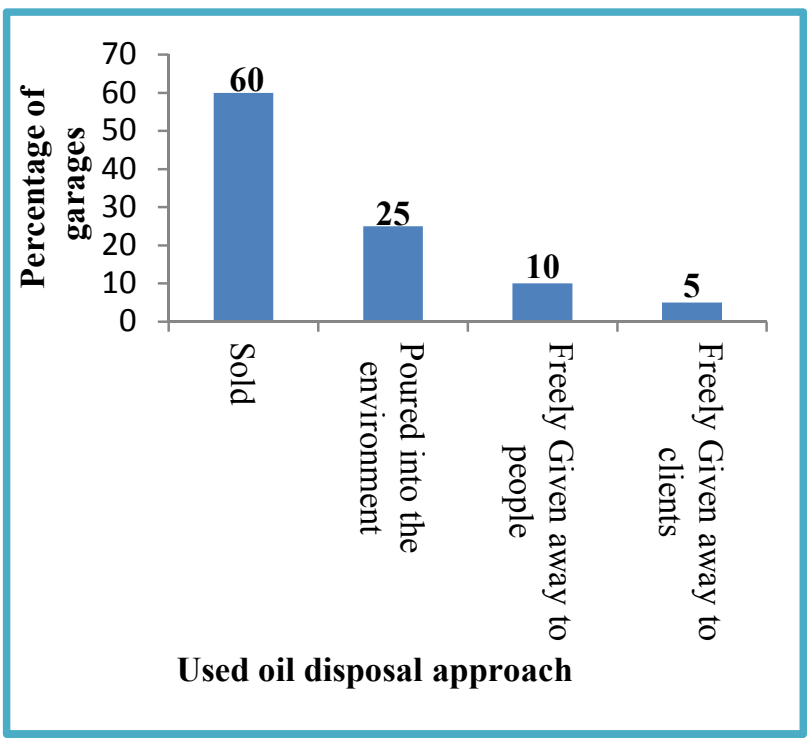

Fig. 8. Used oil disposal methods by garages. 


\section{Discussion}

\subsection{Educational Levels and Working Experience of Mechanics in the Auto Repair Garages}

Automobile vehicle repair garages generate lots of wastes. The major environmental wastes generated by the automotive manufacturing industry include: machine lubricants and coolants; aqueous and solvent cleaning systems; paint; and scrap metals and plastics. Hazardous cleaning chemicals are very common and are likely to require special waste management arrangements [9]. Surely, auto-mechanics requires relatively higher levels of formal and informal education to enable them appreciate issues of good housekeeping including the use of preventive maintenance in an effort to reduce the number of leaks and spills of used oils that occur. Certainly, in most developed countries such as the USA, Germany, Japan, China etc. a high school diploma or the equivalent is typically the minimum requirement for someone to work as an automotive service technician or mechanic. High school courses in automotive repair, electronics, computers, mathematics, and English provide a good background for prospective automotive service technicians. Therefore, completing a vocational or other postsecondary training program is considered as just the preparation for entry-level positions in automotive service technology. Moreover, in developed countries as well as developing countries such as Malaysia, India and currently Ghana, some service technicians can earn an associate's degree. Courses usually include basic mathematics, computer, electronics, and automotive repair. Some programs add classes in customer service, English, as well as other necessary skills in automotive wastes generation and recycling [10].

As identified in fig. 1 of this work, a large majority (74\%) of the auto mechanics, in the informal micro and small scale auto repair sectors in the country possesses formal education up to basic levels. Really, as a result of their low educational levels, the mechanics in the informal sector tend to have general apathy towards the environment despite their appreciable number of years of working experience (fig.3). Undeniably, visits to most of these garages shows that automotive repair wastes in the form of liquids, gases and solids are indiscriminately and instinctively dumped by the mechanics in their auto servicing workshop environments.

The situation whereby most of the mechanics in the informal sector tend to have gross disregard for the environment due to their low levels of formal education call for serious concern. This is because most of the auto repair activities carried out in this country is undertaken by the garages in the informal micro and small scale sector as observed by the Director in charge of Environmental Education at the EPA-Ghana, Salu (2013), who made a presentation on the theme, "The status of waste management in small garages". According to him, a research conducted by the EPA on four small garages in Accra and Tema shows that most of the small-scale garages in the country operated in residential areas, particularly in densely populated areas, and there is the need for the operators such as the auto mechanics to understand the responsibilities of automobile servicing and repairs and take the necessary actions to improve the environmental management of their operations. He further indicated that, the Environmental Protection Agency (EPA) had, for a long time, been concentrating its monitoring activities on large garages, a situation which has left the micro and small scale informal sector garages to have a field day [11].

Frankly, to enable the mechanics in the informal sector to identify with basic environmental issues and therefore develop positive attitudes towards the environment, it is expedient that the mechanics and their masters in this sector take advantage of the education offered by the non-Formal Education Division of the Ministry of Education, which is concerned with adult literacy to upgrade and update their formal education and skills. Again, the auto mechanics can also enroll on the part time Higher National Diploma (HND) programs run in some polytechnics in the country such as Accra Polytechnics to enable them acquire higher certificates, diplomas and degrees particularly in automotive technology. Ultimately, an implementation of the model of education as proposed by Donkor (2006), will serve a useful purpose of helping to educate mechanics who essentially had their education through the apprenticeship system of education. Indeed, this model of apprenticeship envisages apprenticeship training to take place at workshops (on-site) and through distant education (off-site), via radio and television broadcasts, audio-tapes and video-cassettes [12].

Surely, the afore-mentioned measures will culminate in the proper understanding of the environment by the mechanics and will consequently lead to their proper handling and safe disposal of their generated solid, gas and liquid wastes. There will also be significant drop in both indoor and outdoor pollution levels caused by the garages in the country leading to improved health of the people.

\subsection{Education and Training on Hazards of Used Oil for Auto Mechanics}

Used oils can have detrimental effects if spilled or released into the environment, and therefore are considered as hazardous substances. To this end, most garages globally tend to organize training programs to educate auto mechanics on the good housekeeping approaches to adopt to manage and minimize the spill of used oil in the shop floors or garages. Good housekeeping methods include improved employee training, management initiatives to increase employee awareness of the need for and benefits of waste minimization, and requiring increased use of preventive maintenance in an effort to reduce the number of leaks and spills that occur.

Unfortunately, as indicated in fig. 5, a very large percentage of the informal sector mechanics do not have training on the hazards of used oil. Consequently, the mechanics are completely oblivious about the health and environmental hazards of used oil. Observations reveals that the informal sector auto mechanics are not able to identify, recover and appropriately dispose of all hazardous wastes such as used oils, oil filters, oil contaminated rags, etc. Again, the mechanics are 
also ignorant about basic environmental issues such as global warming, ozone depletion, air and water pollution, worker safety and chemical risks, hazardous waste labeling, waste minimization methods, recycling waste and use of recycled products, spill prevention and other related issues.

Really, visits to most of these informal sector small scale garages show that spills from motors, differentials and transmissions, brake and power steering units as well spills from oil filters are allowed to drop freely the shop floor of the garages in enormous proportions; a situation which is objectionable as far as the environment is concerned. Furthermore, broken gallons of used oils as well as oil filters and rags soaked in used oils are voluminously speckled around the service compounds of these informal sector garages exposing the mechanics ignorance about the health and environment hazards associated with these materials. In fact, the mechanics carry out their activities of blanket dumping of hazardous materials with impunity and without any regard for environmental laws or standards.

Again, discussions with the garages in the informal sector reveals that the Environmental Protection Agency-Ghana hardly visit the micro and small scale garages in the country to educate the mechanics about the health and environmental hazards of used oil and other related issues. This definitely is regrettable. The EPA-Ghana should regularly visit the garages in the informal sector which are strewed all over the country and educate them on environmental issues. This will enable the automotive repair garages to shun the haphazard dumping of their generated wastes such as used oils in their work service compounds. Other training centers in the country such as Gratis Foundation, Intermediate Technology Transfer Units (ITTU), Technical training institutions etc. available in the country should also help to educate and alert the informal sector auto mechanics on environmental issues in relation to their operations.

Moreover as indicated in fig. 6, a good number of the automotive garages in the formal sector frequently organize training programs to educate the auto-mechanics on relevant issues of auto repair. Again, visits to the garages in the formal sector which includes garages belonging to the international automotive companies such as Silver Star Ltd, Toyota Ghana Ltd, Rana Motors, Mechanical LIoyed, PHC Motors etc. clearly shows that they organize in-service training programs to educate and train their mechanics and staff on how to repair and maintain essentially their imported vehicles. Indeed, as a result of education and training, the mechanics in these garages endeavor to avert used oil spills and improper handling and disposal of oil filters and rags containing used oils. Generally, these formal sector garages rather have positive attitudes towards the environment and make an effort to achieve pollution free environmental operations.

Nonetheless, an informal discussion with the mechanics in the formal sector indicates that they still need more education on the health and environmental hazards of used oil. Again, discussions with the formal sector garages reveals that the Environmental Protection Agency-Ghana, pays visits to these garages at least twice in a year to ensure that these garages operate their workshops in such a manner so as to avoid polluting the environment with prejudice. The EPA should do more to educate the mechanics about the hazards of used oil.

\subsection{Availability of Used Oil Storage and Disposal Standards in Automobile Repair Garages}

Used oil contains toxic substances that can kill plants and animals, spoil water supplies and even cause cancer. When used motor oil is spread on the land, soil productivity is reduced and surface or ground supplies may be contaminated. One quart of used oil will foul the taste of 250,000 gallons of water. Oil in surface waters severely disrupts the life-support capacity of the water. Oil encourages the growth of organisms that deplete the dissolved oxygen supply available to aquatic life, such as fish. Without oxygen, they die. Oily films on the surface block sunlight, affecting the growth of plants and the direct entry of airborne oxygen. The toxic substances in used oil kill the small organisms that support the rest of the food chain. Used motor oil must be handled carefully because it contains carcinogenic and other toxic substances. Among the more serious health hazards is the large amount of lead found in much of the used oil. Leads and other dangerous compounds accumulate through the combustion process in the engine of a vehicle. Used motor oil must be processed to remove toxic contaminants before it can be safely reused. Mensah-Brown (2013) presented a comparative analysis of Society of Automotive Engineers (SAE) new oil, used oils and re-refined oil (table 2). The study clearly indicates the relatively large amounts of lead and other metals contained in used oils [6].

Table 2. Characteristics of used and re-refined motor oils.

\begin{tabular}{llll}
\hline & \multicolumn{3}{c}{ Sample } \\
\hline Test & New SAE 40 Oil & Used Oil & $\begin{array}{l}\text { Re-Refined } \\
\text { Oil }\end{array}$ \\
Water Content $(\% \mathrm{~V} / \mathrm{V})$ & 0.0 & 0.1 & 0.0 \\
Fuel dilution $(\% \mathrm{~V} / \mathrm{V})$ & 0.0 & 2.9 & 0.0 \\
Pour point, ${ }^{\circ} \mathrm{C}$ & -20 & -20 & -20 \\
n-pentane Insolubles & 0.0 & 1.69 & 0.0 \\
(weight \%) & & & \\
Benzene Insolubles & 0.0 & 0.911 & 0.0 \\
(weight \%) & & & \\
Neutralization Number & 0.40 & 1.645 & 0.06 \\
(mgKOH/g) & & & \\
Metal Contents (ppm) & & 2813 & 1.86 \\
Lead & 0.0 & 606.5 & 9.56 \\
Calcium & 543.2 & 21.25 & 2.17 \\
Copper & 0.0 & 89.5 & 0.0 \\
Iron & 0.0 & 19.0 & 0.0 \\
Potassium & 0.0 & 2.0 & 0.0 \\
Nickel & 0.0 &
\end{tabular}

Source: Mensah-Brown (2013)

Contamination by the toxic substances in used oil can be a serious health hazard to humans in different ways such as: people may consume the contaminated water directly; toxic substances in used oil become concentrated in water, plants and animals and poison people who may eventually eat them; and direct skin contact over an extended period of time has 
been identified as a potential cause of cancer.

As a result of the numerous environmental and health challenges associated with used oils, automotive repair garages which generate or handle used oil are expected to follow certain good housekeeping practices. These mandatory practices, called "management standards," are developed by the EPA for businesses that handle used oil. The management standards are common sense, good business practices designed to ensure the safe handling of used oil, to maximize recycling, and to minimize disposal. The standards apply to all used oil handlers, regardless of the amount of the oil they handle.

Fundamentally, the EPA's requirements are meant to be followed by all types of businesses that handle used oil including: used oil generators, collection centers and aggregation points, transporters, re-refiners and processers, used oil burners and marketers. Expressly, the EPA's standards on used oil managements principally includes: used oil storage management practices, used oil leaks and spills, record keeping on used oils, mixing of used oils and hazardous wastes, effective management of used oil filters as well as standards on effective cleanup of used oil practices [13-14].

Unfortunately in Ghana, as shown in fig. 4, a very large percentage $(95 \%)$ of the garages in both the formal and informal sector have not obtained any used oil management standards to guide them to safely and properly re-claim, store and dispose their used oil to minimize environmental pollution. The non-availability of used oil management standards in the vehicle repair garages has resulted in a situation whereby the mechanics engage in gross inappropriate handling and disposal of used oils to the detriment of the environment and human health. In fact, as a result of low formal educational levels of the mechanics in the informal sector coupled with lack of training, the mechanics in the micro and small scale garages in the country just allow waste oils from sump, gallons, oil filters, saw dust, rags etc. to tire out and dispense profoundly on their shop floors. Undeniably, some of the mechanics deliberately discharge unacceptable volumes of used oils on their service compounds with the intention of checking soil erosion (fig.9).

Not surprisingly, most of the garages in the informal sector as well some from the formal sector have their auto repair servicing compounds utterly covered with thick coat of used oils. Indeed, the mechanics do not find the need to take urgent steps to clean up spill of used oils. Used oil filters are indiscriminately discarded allowing used oil to drain heavily on the ground to cause environmental pollution. It is not uncommon to find situations like spills-wet patches not cleaned up, absorbent materials not available, floor surface slippery when wet and other similar situations persisting in the informal automotive repair garages in the country with neither the employer nor the mechanics taking responsibility for the on-site health and safety of the whole workforce in the garage. Most garages do not use drip pans and the occurrence of fluids leaking from automobiles and parts placed on the floor are common. Figure (9a and b) shows used oil drained unacceptably on the floor in a small scale garage in Accra.

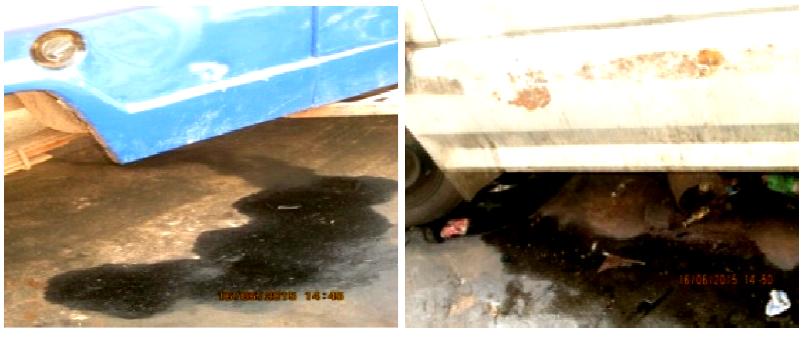

(a)

(b)

Fig. 9. Used oil drained on the floor from vehicles in a small garage in Accra

Nonetheless, by using drip pans, shop floors will remain cleaner and hence less frequent cleaning of the floors would be required. Added benefits would be a reduction in the use of rags and adsorbent to clean the floors, and a safer work environment.

Meanwhile, used oil filters are difficult to completely drain of oil, even after draining, may contain oil trapped inside the filter. Used filters are considered to be source of liquid waste and cannot be placed in a bin or skip for disposal. Filters need to be managed by Hydraulic filter crushers which separate the dirty oil from the filter. Best practice management of oil filter wastes involves the use of a mechanical crusher to remove and recover most of the oil they contain. The free oil removed from the filter must be contained, managed and stored separately (for collection into waste oil storage drums) from the filters. Drained and mechanically crushed oil filters (not containing free liquids) are then classified as solid waste. Some metal recyclers may accept the crushed filters that can then be passed to scrap metal dealers with a much reduced chance of environmental pollution [15-16-17]. Fig. 10 shows typical hydraulic oil filter crushers.

Again, Sawdust and rags are commonly used to absorb a spill of used oils and other hazardous substances in almost all the formal and informal garages in the country. Saw dust used to clean waste oil might be classified as hazardous waste and be subjected to hazardous waste regulations. Undeniably, most garages currently in the country dispose of the used saw dust and rags in the trash. To reduce the environmental effects associated with disposal of dirty rags which might be classified as hazardous, the automobile repair garages in the country should seriously consider the use of leasing arrangements in which a laundry service picks up the dirty rags, cleans them, and returns them to the shop.

Furthermore, management initiatives to increase employee awareness of the need for and benefits of used oil minimization, the increased use of preventive maintenance in an effort to reduce the number of leaks and spills that occur in the garages in the country will help reduce the environmental pollution caused by used oil drains. Additional ways to reduce or minimize waste oil spills include: improve used oil inventory control practices by the garages, use of first-in, first-out (FIFO) policy, minimization of storage quantities, increase storage area inspections as well as employment of spill containment techniques by the automobile repair garages in the country. 

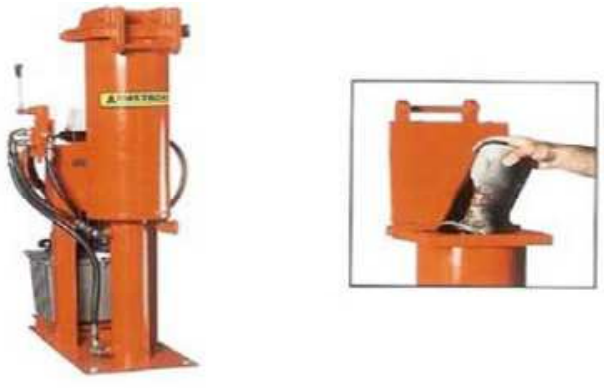

Fig. 10. Hydraulic filter crushers.

\subsection{Used Oil Storage in Automobile Repair Garages}

EPA's used oil storage requirements demands that, all used oil tanks and containers be properly labeled, kept in good condition, be prevented from rust, leak, or deterioration. In addition, structural defects need to be fixed immediately. Certainly, under the EPA's regulations, used oil is never supposed to be stored in anything other than tanks and storage containers. Also, storage of used oil in lagoons, pits, or surface impoundments that are not permitted under EPA regulations and requirements is prohibited $[13,18]$. As shown in fig. 7 , about $85 \%$ of the auto repair garages in the formal and informal sector in the country claims they do not have problems of storing their generated used oils.

However, visits to the informal auto repair garages shows that tanks and gallons which are not properly covered, labeled and not in good conditions are rather utilized by the informal sector mechanics to store used oils particularly outdoor due to lack of storage rooms. Again, these micro and small sector garages lack storage spaces. They only possess small wooden structures in which they store most of their tools and equipments for safe keeping and protection. Certainly, these methods of storing used oils in bare gallons and containers out-door by the mechanics causes water and other contaminants to get into the stored used oils and contaminate it.

Moreover, if used oil is mixed with hazardous waste, it probably will have to be managed as a harmful waste. Hazardous waste disposal is a lengthy, costly, and strict regulatory process. Again, Certified center managers will not be in a position to accept used motor oils that have been contaminated with other fluids such as antifreeze, solvents, gasoline, or water. The only way to be sure that used oil does not become contaminated with hazardous waste is to store it separately from all solvents and chemicals and not to mix it with anything.

As a result of lack of proper used oil storage facilities in the micro and small scale informal auto repair garages, the mechanics ends up discarding their generated used oils into containers in household garbage bins which end up in landfills. Some mechanics also engage in inappropriate use of the used oil including pouring on weeds, spraying on roads as dust suppressant, cleaning tools and protecting timber posts and fences from termites. Again, significant volumes of used oils are disposed directly into the environment, with large majority of the garages in the country pouring more on the ground. This is because most of the work areas in the garages are bare soils that could be used for disposal. Used oil utilization in road construction and in marking play grounds result in release of the used oil components into the environment as identified by Nwachukwa et al (2012). These practices are harmful because the used oil can then enter the soil and leach through to contaminate ground water.

Clearly, this shows that there is a need for information about waste oils, especially for the mechanics in the informal micro and small garages in the country. Training and making available information on handling and storing hazardous materials to these mechanics would significantly reduce their poor storage practices of used oils which will result in reduction in environmental pollution. To help educate and sensitize the mechanics in the informal sector who incidentally undertake most of the vehicle repair activities in the country, the EPA must extend and intensify its education and training programs in these garages. The technical training institutions available in the country including the ITTU, Gratis Foundation, and so on must help to train and educate the mechanics particularly on the environmental impacts of used oils.

On the other hand, the formal sector medium scale auto repair garages, including the international automobile repair garages in the country rather take measures to appropriately store their used oils in well sealed gallons. They tend to be environmental conscious and therefore take steps to reduce used oil spillage in their automotive servicing garages. Indeed, the environmental consciousness exhibited by some of the mechanics in the formal sector could largely be attributed to the mechanics relatively high educational levels, regular training and information being made available to these mechanics. In addition, regular visits by the EPA- Ghana to these formal sector garages in the country also enable the latter to be proactive in ensuring safe environment practices.

Ultimately, the EPA must vigorously enforce its by-laws on the proper handling, storage and disposal of waste oil by the garages in the country. This will enable the mechanics in the country to develop a sense of responsibility towards the environment and do well to avert its pollution disproportionately.

\subsection{Disposal of Used Oil by Garages}

Currently in Ghana, none of the automobile repair garages is able to recycle its generated used oil for re-use. There are also no accredited used oil collection centers available in the country. Additionally, the transporters or buyers of used oil in the country are also not certified and accredited. Subsequently, as shown in figure 8 , a large majority $(60 \%)$ of the garages in both the formal and informal sector in the country do sell their generated used oil essentially to unlicensed used oil boys, popularly called 'gwagwa boys' who are particularly illiterates or school drop-outs and therefore are not informed about the environmental hazards of used oil. From observations, these boys hop from one garage to another during the early hours of the day and acquire the used oils from the various garages. A discussion with these 'gwagwa boys' reveals that they normal purchase one gallon of the used oil (that is 5 Liters) for paltry 
$\mathbb{C} 2$ (currently, equivalent to \$0.56) from the garages. Again, discussions with the 'gwagwa boys' also indicate that they do sell the used oil they have procured from the garages to timber merchants for spray on timber species for protection against termites' attack. Furthermore, the boys also sell off some of the used oils to corn millers, road constructors, who mix the used oils with coal-tar for road constructions, as well as other unlicensed used oil dealers.

Moreover, the Korle Lagoon in Accra has become one of the most polluted water bodies on earth. It is the principal outlet through which all major drainage channels in the city empty their wastes into the sea. Large amounts of untreated industrial waste emptied into surface drains has led to severe pollution in the lagoon and disrupted its natural ecology.

Undeniably, the banks of the Korle Lagoon in Accra, has become one of the major unlicensed used oil collection centers currently in the country, where the 'gwagwa boys' send their used oils for sale after procuring it from the garages. Visits to the Korle lagoon geographical area reveal that gallons of used oils are undeservedly lined up at the banks of this river (fig. 11a and b). Incongruously, these gallons of used oils are allowed to drain continuously into this lagoon on daily basis causing severe pollution of both the lagoon and its contiguous environments. In fact, this situation persists even now. The worrying aspect of it all is that the Korle lagoon has its principal outlet through which all major drainage channels in the city empty their wastes into the sea. This implies that intolerable quantities of used oils are allowed to drain into the sea and other water bodies in the country from the Korle lagoon.

Definitely, to help curb this situation and save the water bodies in the country, the EPA-Ghana, the Accra Metropolitan Assembly as well as other regulatory bodies in the country should as a matter of urgency visit the Korle Lagoon Geographical areas and educate these unlicensed used oil dealers on proper handling methods of used oils. Where necessary, these regulatory bodies should warn the 'gwagwa boys' to desist from using the banks of the Korle lagoon as used oil collection centers. This will help prevent further polluting the lagoon and its vital environs with used oils.

As depicted in table 2, used motor oil is insoluble, persistent, and can contain toxic chemicals and heavy metals. When disposed improperly, used oil can contaminate soil and water (table 1). Fortunately, used motor oil can be recycled and either re-refined into new oil, processed into fuel oils, or used as raw materials for the petroleum industry.

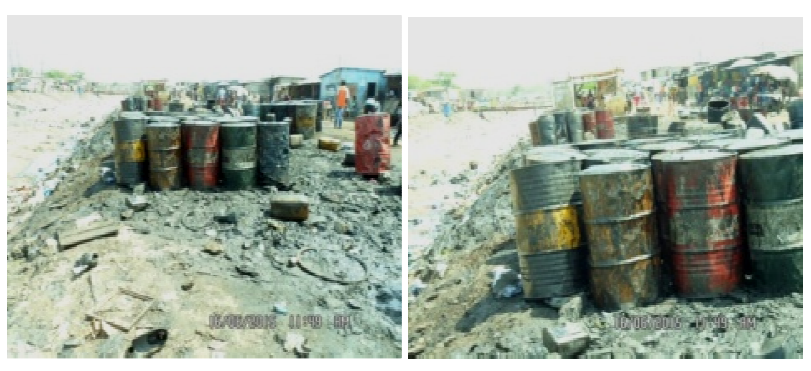

(a)

(b)

Fig. 11. Gallons of used oil at banks of Korle Lagoon in Accra
To help ensure proper storage and more particularly appropriate disposal of used oils, most developed countries such as the USA, China, Japan, Australia, and so on encourage the recycling of used motor oil by sitting and certifying used oil recycling collection centers in most of its cities and towns . This ensures that certified used oil collection centers take used motor oil from the public at a fee for recycling. Essentially, these countries also promote the establishment of tribal used oil collection and recycling centers where the tribal and/or community members send their generated used oils to a drop-off location run by the tribe [19].

Even so, currently in Ghana, there are no licensed used oil collection centers in any of the regions or communities in the country leading to improper handling and disposal of the used oils by the garages in particular. The government of Ghana through the public-private partnership initiatives should help establish licensed used oil collection centers in strategic locations in the country where all used oil producers could be encouraged to send their generated used oils for sale, instead of selling them to the unlicensed 'gwagwa boys' who lack the requisite knowledge in proper used oil handling methods. The banks, corporate organizations, worthy business men and women in the country should also help in this direction.

Globally, four major reasons are driving this momentum of refining used oil. Firstly, the quality of re-refined base oils is improving dramatically. There has been an overall upgrading in the refining processes and in the quality of used oils collected due to better collection practices. Secondarily, rising crude oil prices have driven up base oil prices, making re-refining economically attractive. Thirdly, recent studies by the US Environmental Protection Agency have also revealed that there are significant economic benefits of waste oil refining. Tests conducted have shown that reprocessing used oil consumes far less energy and resources than refining crude oil from the earth. For example, it takes only 4 litres of used oil to produce 2.5 litres of new engine oil. But when starting from scratch, that same 2.5 quarts would require 160 litres of unrefined crude oil to manufacture. Finally, environmental standards across all countries, developed and developing, are becoming stringent. Tests have shown that 4 litres of oil dumped into a river can contaminate 4 million liters of water and have disastrous effects on our planet's ecosystem [2].

In fact as a result of many benefits associated with recycling of used oils, many local governments in most developed countries provides funds and logistical supports to the vehicle repair garages to enable them recycle their generated used oils in-house. These supports includes; awarding grants, subsidies, loans, and other financial supports to municipalities, parishes, political subdivisions, and vehicle repair garages to enable them establish and provide continuous operation of collecting services and facilities for used oil [19].

Moreover, Statistics from the National Petroleum Authority of Ghana and the Tema Lube Oil Company Limited indicate that the total domestic consumption of lubricating oils as far back as 2013 was about 45 million liters which amounts to about US\$1050 million at current exchange rate of US\$1.00= GHC4.20 (20/6/2015). This constitutes a huge chunk of the 
foreign exchange requirement of the country with a nominal Gross Domestic Product (GDP) of US\$48.678 billion for 2013 [20].

The government of Ghana should as a matter of urgency help partner the local garages in Ghana to procure the necessary equipments to enable them recycle their generated used oils in-house. Definitely, the establishment of re-refining and/or reprocessing as a strategy for used oil management in Ghana would significantly reduce the amounts of this common hazardous material being disposed arbitrarily into the environment to pollute it. Also, government spending on the importation of virgin engine oils into the country will considerably trim down.

\section{Conclusion}

This paper investigates used oil storage and disposal practices in the automotive repair garages in Ghana. The study shows that used oil storage and disposal practices in the auto repair garages in the country are rather indecorous, inapt, futile and unprofessional leading to nauseating environmental pollution by the auto repair garages in the country. The study also reveals that large majority of the garages in both the formal and informal sector do not possess waste oil standards to guide them to properly reclaim, store and dispose off their generated waste oils. Again, most of the mechanics in the auto repair garages in the country are completely oblivious about the health and environmental hazards associated with used oils due to lack of training and education. Furthermore, none of the garages currently in the country recycles used oil for re-use. There are also no certified used oil collection centers in any part of the country. This has created a situation whereby the mechanics ends up engaging in improper handling and disposal of the used oils including discarding it into containers in household garbage bins, pouring the used oil on weeds, spraying it on roads as dust suppressant, cleaning tools and protecting timber posts and fences and so on. Moreover, significant volumes of used oils are disposed directly into the environment, with large majority of the garages in the country pouring more on the ground. To help reverse this trend and to enable the mechanics adopt and adapt proper methods of storing and disposing used oils without polluting the environment excessively in the country, the EPA's by-laws on used oils handling and disposal practices must be made stringent and vigorously enforced. The EPA must also intensify its visits to the garages and educate and sensitize the mechanics about the health and environmental effects of used oils. This will enable the mechanics in the country to develop a sense of responsibility towards the environment and do well not to allow their generated used oils to pollute it unjustifiably. The government must provide financial and other logistical supports to the auto repair garages in the country to enable them procure the relevant equipments to recycle their generated used oils. The Banks, corporate organizations, philanthropies as well as wealthy individuals in the country should help establish used oil collection centers in most of the communities in the country to enable the mechanics sell off their generated used oils for recycling. This will prevent the mechanics from pouring the used oils into the environment as well as selling it to unauthorized dealers such as 'gwagwa boys' who virtually knows nothing about the health and environmental hazards of used oils. Indubitably, the recycling of used oils in the country will not only reduce the unwarrantable dumping of the used oils by the mechanics and other unlawful dealers but will also create more jobs and enhance the revenue base of the government.

\section{References}

[1] Waste Oil Study Report to Congress, Prepared by the US Environmental Protection Agency (EPA), Washington, USA, 1974

[2] W.A. Irwin ,1978, Used oil: Comparative Legislative Controls of Collection, Recycling, and Disposal, pp.703-705

[3] S. Jhanani, J. Kurian, Used oil Generation and Manage ment in Automotive Industries, Environmental Assessment of Used Oil, vol. 2, 2011, pp. 135-138

[4] B.O. Okonokhua, B. Ikhajiagbe, G.O. Anoliefo, and T.O. Emed, "The Effects of Spent Engine Oil on Soil Properties and Growth of Maize (Zea mays L.)" 2007, pp. 147 - 152

[5] M.A. Nwachukwu, J. Alinnor, and H. Feng, "Review and Assessment of Mechanic Village Potentials for Small Scale Used Engine Oil Recycling Business, 2012, pp.465-474

[6] H. Mensah-Brown, "Optimization of the Production of Lubricating Oil Using Response Surface Methodology”, 2013, pp. $749-756$

[7] J. Powell, "Survey of Engineering Manufacturing Industries in Ghana. Technology and Enterprise Development Project". A Report of DFID, London, UK. 1995.

[8] I.R. Levin, "Qualitative Approach to Management", McGraw-Hill, Singapore, 1989

[9] RCRA In Focus, "Vehicle Maintenance", 1999

[10] Study.com, "Automechanic Training Programs and Requirements", 2015

[11] ModernGhana, Daily Graphic/Ghana, "Waste Dis-posal by Garages Endangers Public Health”, 2013

[12] Francis Donkor, Department of Technology Education, University of Education, Winneba "Enhancing Apprenticeship Training in Ghana Through Distance Learning",2006

[13] USEPA, "Managing Used Oil: Advice for Small Business", 2015

[14] USEPA, "Standards for the Management of Used Oil, Part 280, 2015

[15] EPA, "Guides to Pollution Prevention, the Automotive Repair Industry", 1991

[16] M. G. Elnour, H.A. Laz, "Clean Production in Autorepair Workshops", 2013, pp. 66-77

[17] D.V. Jacobs, "How to Design and build your AutoWorkshop, publish. motorbooks intern, USA, 1998 
[18] Ohio EPA, , "The Regulation of Used Oil: An Overview for Ohio Businesses who generate Used Oil”, 2015

[19] R. Arner, 2012, Used Oil Recycling in America
[20] The State of the Ghanaian Economy in 2013. Institute of Statistical, Social and Economic Research (ISSER), University of Ghana, Legon, 2014. 